http://dx.doi.org/10.11646/phytotaxa.00.0.0

\title{
Pholiota oblita, new species in sect. Adiposae stirps Subflammans (Strophariaceae, Agaricomycetes), from the Argentinean Yungas
}

\author{
NICOLÁS NIVEIRO ${ }^{1 ; 4}$, ORLANDO F. POPOFF ${ }^{1}$, BERNARDO E. LECHNER ${ }^{2} \&$ EDGARDO O. ALBERTÓ $^{3}$ \\ ${ }^{1}$ Instituto de Botánica del Nordeste, IBONE (UNNE-CONICET). Sargento Cabral 2131, CC 209 Corrientes Capital, CP 3400, \\ Argentina \\ ${ }^{2}$ PROPLAME-PRHIDEB (UBA-CONICET), DBBE, FCEN, UBA. Intendente Güiraldes 2160, C.A.B.A., Buenos Aires, CP 1428, \\ Argentina. \\ ${ }^{3}$ Instituto de Investigaciones Biotecnológicas- Instituto Tecnológico de Chascomús. IIB-INTECH (UNSAM-CONICET). Cam. Circ. \\ Laguna Km. 6, Chascomús, Buenos Aires, CP 7130, Argentina \\ ${ }^{4}$ Author for correspondence, email: niconiveiro@gmail.com
}

\begin{abstract}
We present a study on the genus Pholiota sect. Adiposae stirps Subflammans from the Republic of Argentina. Pholiota oblita is proposed as a new species. It is characterized by its narrow lamellae, elongated cheilocystidia and broad spores. Singer originally described this species as $P$. digilioi, but this name was never validly published. Pholiota oblita is close to P. flammans, from the Northern Hemisphere, and P. subflammans, from the South American Andino-Patagonic forest, but differs by the diagnostic characters previously mentioned. The species was found in the southern end of the Yungas Forest, a cloud forest located on the eastern slopes of the sub-Andean mountains. Numerous collections of $P$. oblita were found in the Yungas forest but not in other areas. We believe that it could be an endemic species. Furthermore, we found that there are no herbarium specimens for the type of Pholiota subflammans (Speg.) Sacc. With the absence of original material, and to preserve current usage of the name, a neotype is designated hereby. The neotype chosen for $P$. subflammans is a specimen determined, described, and collected by Singer in the same area where the type specimen was found by Spegazzini.
\end{abstract}

Key word: Agaricales, Pholiota oblita, P. digilioi, P. subflammans, new species, neotype

\section{Introduction}

Pholiota (Fr.) P. Kumm. is a genus of the family Strophariaceae (Agaricomycetes). It is characterized by its fibrillose to squamose, viscid and glutinous to dry, typically yellowish, rusty yellow or brownish pileus, with appendiculate margin; lamellae close, yellowish at first; stipe smooth to squamose, with an annulus or at least a fibrillose area on the partial veil insertion; spore print rusty or ochraceous brown. Microscopically, spores are smooth, with an apical germ-pore; the pileipellis is a cutis or ixocutis, pleurocystidia are present or absent, if present either leptocystidia or chrysocystidia; clamp connections always present (Largent \& Baroni 1988, Singer 1986). The stirps Subflammans is characterized by its yellow-brown to yellow basidiomata, not tending to any rusty, orange-red, warm sepia or violet-brown colours, with the pileus surface covered with conspicuous, floccosesquarrose scales, that eventually disappear because the strongly gelatinous underlying epicuticular layer is obliterated by weather and age (Singer 1986: 580).

In Argentina, 28 species of Pholiota are known; most of these recorded from the central region and the Andino-Patagonic forests (Niveiro \& Albertó 2012). The aim of this work is to contribute to the knowledge of stirps Subflammans from Argentina, describing a new species and designating a neotype for P. subflammans (Speg.) Sacc. 


\section{Material \& methods}

Macroscopic description is based on fresh material, according to Largent (1986) and Lodge et al. (2004). Color abbreviations follow Maerz \& Paul (1930). Microscopic features are described from material mounted in $5 \% \mathrm{KOH}$, phloxine (1\%), and Melzer's reagent. The following notations are used: $x=$ arithmetic mean of the spore length and width; $\mathrm{Q}=$ quotient of length and width indicated as a range of variation; $\mathrm{Q}_{x}=$ mean of $\mathrm{Q}$ values; $\mathrm{n}=$ number of spores measured. Herbarium specimens are deposited in CTES, BAFC, and LIL. Herbarium abbreviations follow Thiers (2013).

\section{Result: Taxonomic treatment}

Pholiota oblita Niveiro, Popoff \& Albertó, sp. nov. (Figs. 1, 3A)

= Pholiota digilioi Singer fide Singer (1952: 498), invalid name.

Mycobank \# MB 805226

Diagnosis:- Similar to Pholiota flammans and P. subflammans, but with narrower lamellae, elongated cheilocystidia and broader spores.

Type: - ARGENTINA. Salta: Santa Victoria Oeste, Baritú National Park, El Lipeo, trail to Termas del Cayotal (22॰25'38.1'S 6444'24.7’'W, 1230 m elev.), 21 April 2009, N. Niveiro 976b (Holotype CTES!).

Basidiomata gregarious, caespitose, on humus. Pileus 7-30 (40) mm broad, convex to hemispheric, becoming broadly convex, slightly umbonate, surface yellowish brown (M\&P 11-G2 to M\&P 11-J7), with darker center, to brownish orange (M\&P 9-K7), viscid, with small, recurved, fibrillose scales, concolorous with the pileus surface, that eventually "disappear" at maturity, moving in the viscous surface towards the bottom of the gelatinous layer. Margin smooth or appendiculate with veil remnants, not striate. Context fleshy, thin, cream to yellowish color. Odor and taste not tested. Lamellae regular, yellowish, turning chestnut when touched or with age, narrow, to 2.5 $\mathrm{mm}$ broad, close, adnate with small tooth, even colorous margin, with lamellulae. Stipe central, 25-42 $\times 2-4 \mathrm{~mm}$, cylindrical, equal or slightly enlarged at base, yellow (M\&P 10-H1) to yellowish brown (M\&P 10-J6), with abundant recurved scales from the ring to the base. Annulus ascending, fixed, floccose. Spore print light brown.

Spores 6-7.5 $\times 3.8-5.5 \mu \mathrm{m} ; x=6.7 \times 4.3 \mu \mathrm{m} ; \mathrm{Q}=1.18-1.79 ; \mathrm{Q}_{x}=1.54 ; \mathrm{n}=75$; ovate to ellipsoidal, olive brown, with a small apical germ pore, slightly truncated apex, smooth, slightly thickened wall. Basidia $17-22.5 \times 5-7 \mu \mathrm{m}$, clavate, 4-spored, hyaline, thin-walled. Pleurocystidia 21.5-50.5 $\times 5.6-14.8 \mu \mathrm{m}$, clavate-mucronate to fusoidventricose, chrysocystidia type, with content amorphous and granular-aggregated forming folded (reticulate) masses. Cheilocystidia 33-47 $\times 5.5-8.2 \mu \mathrm{m}$, cylindrical with rounded apex to slightly capitate, thin-walled, hyaline, with homogeneous content. Hymenophoral trama regular, hyaline hyphae 5-8 $\mu \mathrm{m}$ diam., subhymenium of narrow, hyaline somewhat interwoven gelatinous hyphae. Pileipellis a thick ixocutis $(120-150 \mu \mathrm{m})$ with cylindrical, pale yellow hyphae, incrusted with brown pigment, 3-6 $\mu \mathrm{m}$ diam., immersed in the gelatinous matrix. Clamp connections present.

Distribution and ecology:- Growing on humus in the Montane Forest of northwest Argentina, from Tucumán (Singer 1952), Salta, and Jujuy Provinces (Fig. 4).

Additional specimens examined (paratypes):- ARGENTINA, Salta: Santa Victoria Oeste, El Nogalar de los Toldos Natural Reserve, trail to Santa Victoria (22 ${ }^{\circ} 16^{\prime} 46.6^{\prime \prime S} 64^{\circ} 42^{\prime} 35.0^{\prime \prime} \mathrm{W}, 1677 \mathrm{~m}$ elev.), 25 April 2012, $N$. Niveiro 2590 (BAFC!), 2596 (LIL!), 2598 (CTES!), E. Albertó 2707 (CTES!). Jujuy: Ledesma, Calilegua National Park, Bosque del Cielo trail (2340'87.6'S 6454'08.4'W, 1695 m elev.), 27 April 2012, N. Niveiro 2622, 2625 (CTES!). Tucumán: Santa Rosa, ad terram in silvis subtropicali vel Montana sub Phoebe, Eugenia, alno, etc., 17 Dec. 1950, leg. R. Singer T 1058 (LIL!). Ib. "quebradita" near the Tafí del Valle, alt. 2350 m, 11 Jan. 1950, leg. $R$. Singer $846 a$ (LIL!). Ib. Rio de los Sosas, ad terram arenosam supra radices arboris dicotyledoneae ad ripam fluminis, alt. 950 m, 26 Feb. 1952, leg. R. Singer T 1907 (LIL!). Ib. Anta Muerta, Sierra de San Javier, ad terram humosam (nunquam ad ligna), fasciculariter crescents in silva montano-subtropicali, 3 Nov. 1949, leg. R. Singer $T$ 757 (LIL!). Ib. Parque Aconquija, Sierra de San Javier, ad terram vel ad lignum submersum putridis simun in humo silvestri in silva montano-subtropicali, 17 July 1949, leg. R. Singer T 601 (LIL!). Ib. Anta Muerta, Sierra de San Javier, ad humum lignosum in cave trunci in silva montano-subtropicali, 19 Dec. 1949, leg. R. Singer T 794 (LIL!). 
$I b$. Sierra de San Javier, Ciudad Universitaria, in subtropical forest (upper level) on a dead dicot trunk together with Pleurotus ostreatus, 12 May 1957, leg. R. Singer T 3097 (LIL!).

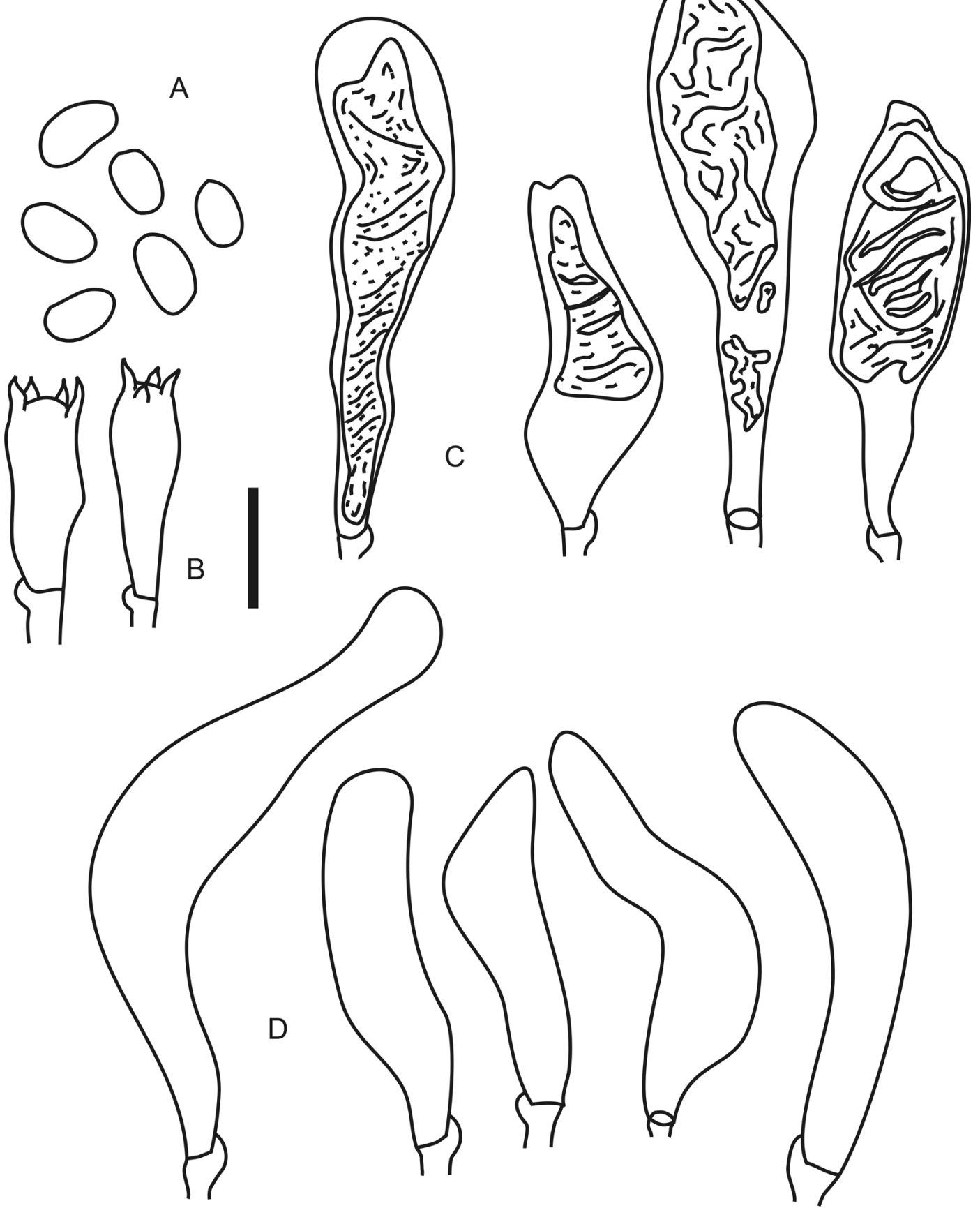

FIGURE 1: Pholiota oblita [Niveiro 976b (CTES)]: Microscopic characters: A—spores, B—basidia, C—pleurocystidia (chrysocystidia type), D-cheilocystidia. Bar $=10 \mu \mathrm{m}$.

Remarks:-This species was originally described by Singer as $P$. digilioi Singer, based on material collected in Tucumán Province (Singer 1952: 496). It was not considered a validly published species because no Latin diagnosis was included and no type material was designated (McNeill et al. 2012). Although Singer (1952: 496) mentioned that he would formally describe it in the future, he never did publish it. No other description was published after that, and no further record of this species was found (Mueller \& Wu 1997). For this reason we have named this species with the epithet oblita, which means "forgotten" in Latin.

Pholiota oblita is characterized by its narrow lamellae, large cheilocystidia and slightly broad spores. It belongs to the subgenus Pholiota, section Adiposae, stirps Subflammans because it has yellowish basidiomata 
covered by conspicuous scales, at first flocose-squarrose, erect, separable scales, that eventually "disappear" at maturity moving towards the bottom of the gelatinous layer (Singer 1986: 580, Smith \& Hesler 1968: 166).

Other species from stirps Subflamans related to P. oblita include P. flammans (Batsch) P. Kumm., known from the Northern Hemisphere, and P. subflammans (Speg.) Sacc., from the South American Andino-Patagonic forest. Both species differ from P. oblita by their smaller spores: 4-5 $\times 2.5-3 \mu \mathrm{m}$ in P. flammans (Smith \& Hesler 1968: 167 ) and 5-6.3 $\times 3-3.4 \mu \mathrm{m}$ in P. subflammans (Spegazzini 1887a, 1887b, Horak 1967: 358); less elongated cheilocystidia, 18-20 $\times 3 \mu \mathrm{m}$ in P. flammans (Smith \& Hesler 1968: 167), 17-22 $\times 6-8.2 \mu \mathrm{m}$ in P. subflammans (Singer 1952: 497); and wider lamellae, which are moderately broad to broad in both species (Smith \& Hesler 1968: 167, Singer 1952: 499). Moreover, P. flammans differs from the other species in its more robust basidiomata, with larger pileus and wider stipe (Smith \& Hesler 1968: 167). Both species were found in colder zones than $P$. oblita (Smith \& Hesler 1968: 167, Singer 1952: 499).

Singer (1952: 498) described slightly shorter spores $(5-8.8 \times 3.5-4.8 \mu \mathrm{m})$ for Pholiota digilioi than the present description, but the remaining morphometric characteristics (basidia, chrysocystidia, cheilocystidia) are identical in both descriptions.

Moreover, when Singer (1952: 497) analyzed the Spegazzini type material from Tierra del Fuego and topotype material collected by himself of $P$. subflammans, he described similar spores $(5.5-7 \times 3.7-4.2 \mu \mathrm{m})$ to $P$. digilioi, differing from the observations made by Spegazzini (1887a, 1887b) and Horak (1967). However, upon reanalyzing the materials examined by Singer (1952: 497), we observed that $P$. subflammans has slightly narrower spores and shorter cheilocystidia (Fig. 2).

According to the characters mentioned above (and outstanding in the key and Table 1) we propose P. oblita (=P. digilioi ss. Singer 1952) as a new species, similar to P. flammans and P. subflammans (=P. baeosperma), being, so far, an endemic species from the southern Yungas Forest.

TABLE 1: Distinctive characters of three species of Pholiota stirps Subflammans. * data obtained from Smith \& Hesler (1968: 167), ** data obtained from Singer (1952: 497).

\begin{tabular}{lccc}
\hline & P. oblita & P. subflammans & P. flammans \\
\hline Basidiomata (diam.) & $7-30(40) \mathrm{mm}$ & $20-38 \mathrm{~mm} * *$ & $(30) 40-80(100) *$ \\
Lamellae breadth & $1.5-2.5 \mathrm{~mm}$ & $3-4.5 \mathrm{~mm} * *$ & "moderately broad to broad"* \\
Spores & $6-7.5 \times 3.8-5.5 \mu \mathrm{m}$ & $5.3-7 \times 3-4.5 \mu \mathrm{m}$ & $4-5 \times 2.5-3 \mu \mathrm{m} *$ \\
Cheilocystidia & $33-47 \times 5.5-8.2 \mu \mathrm{m}$ & $16-22 \times 3.5-7 \mu \mathrm{m}$ & $18-20 \times 3 \mu \mathrm{m} *$ \\
\hline
\end{tabular}

Pholita subflammans (Speg.) Sacc., Syll. Fung. 9: 91, 1891 (Figs. 2, 3B)

三Agaricus subflammans Speg., Boln. Acad. Nac. Cienc. Córdoba 11(1): 10, 1891.

= Pholiota baeosperma Singer, Sydowia 7: 217, 1953. Fide Horak (1967).

Neotype (designated here):- ARGENTINA, Tierra del Fuego: Est. Nueva Argentina, ad terram in silvis sub Nothofago antarctica, 11 Feb. 1950, leg. R. Singer M 180 (LIL!).

Distribution and ecology:- Growing on humus of Andino-Patagonic forest from South America, from Tierra del Fuego to Neuquén provinces (Spegazzini 1887a, Singer 1952, Singer \& Digilio 1952, Niveiro \& Albertó 2012b) (Fig. 4).

Additional specimens examined:- ARGENTINA, Tierra del Fuego: Est. Nueva Argentina, in silvis nothofaginensis ( $N$. antarctica) inter gramina ad terram, 16 Feb. 1950, $R$. Singer M 307 (LIL!), Neuquén: Nahuel Huapi National Park, trail to Los Cántaros, on woody humus in woods, 16 Feb. 1960, R. Singer M 3019 (LIL!), Ib. Nahuel Huapi lake, Pto. Blest, in Nothofagus-Saxegothaea woods among herbaceous plants, on humus, 16 Feb. 1960, R. Singer M 3008 (LIL!).

Remarks: The type material of $P$. subflammans deposited in LPS herbarium and originally described by Spegazzini (1887a) is lost (Chayle, pers. comm.). Horak (1967: 358), who reanalyzed the type material of $P$. subflammans, noted that the type specimen consisted of remnants in poor condition. For this reason, a collection made by Singer in 1950 and described in Singer (1952: 497) which is in good condition and was collected in the Estancia Nueva Argentina (Tierra del Fuego province), (the same place where the original collection was made by Spegazzini) is proposed as the neotype of this species. 


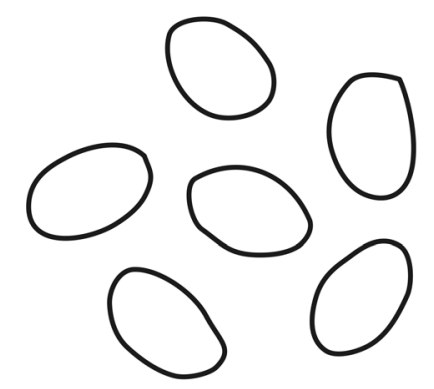

A

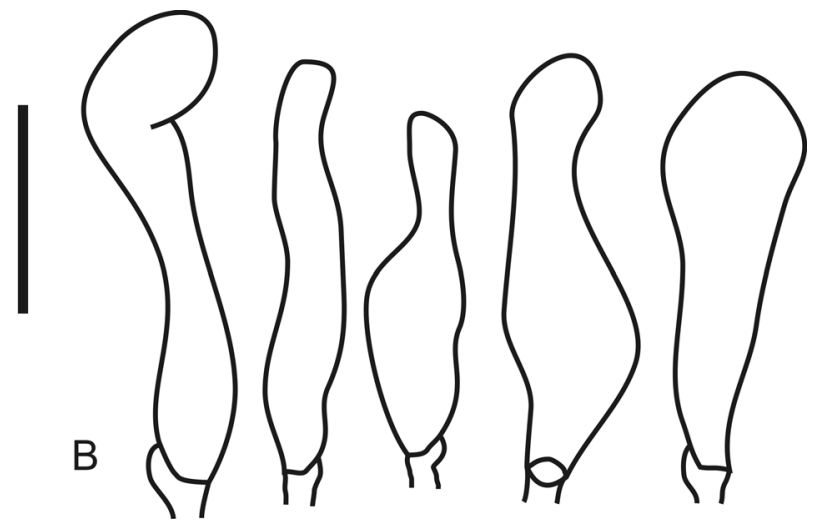

FIGURE 2: P. subflammans: microscopic features. A-spores, B — cheilocystidia. Bar $=10 \mu \mathrm{m}$.
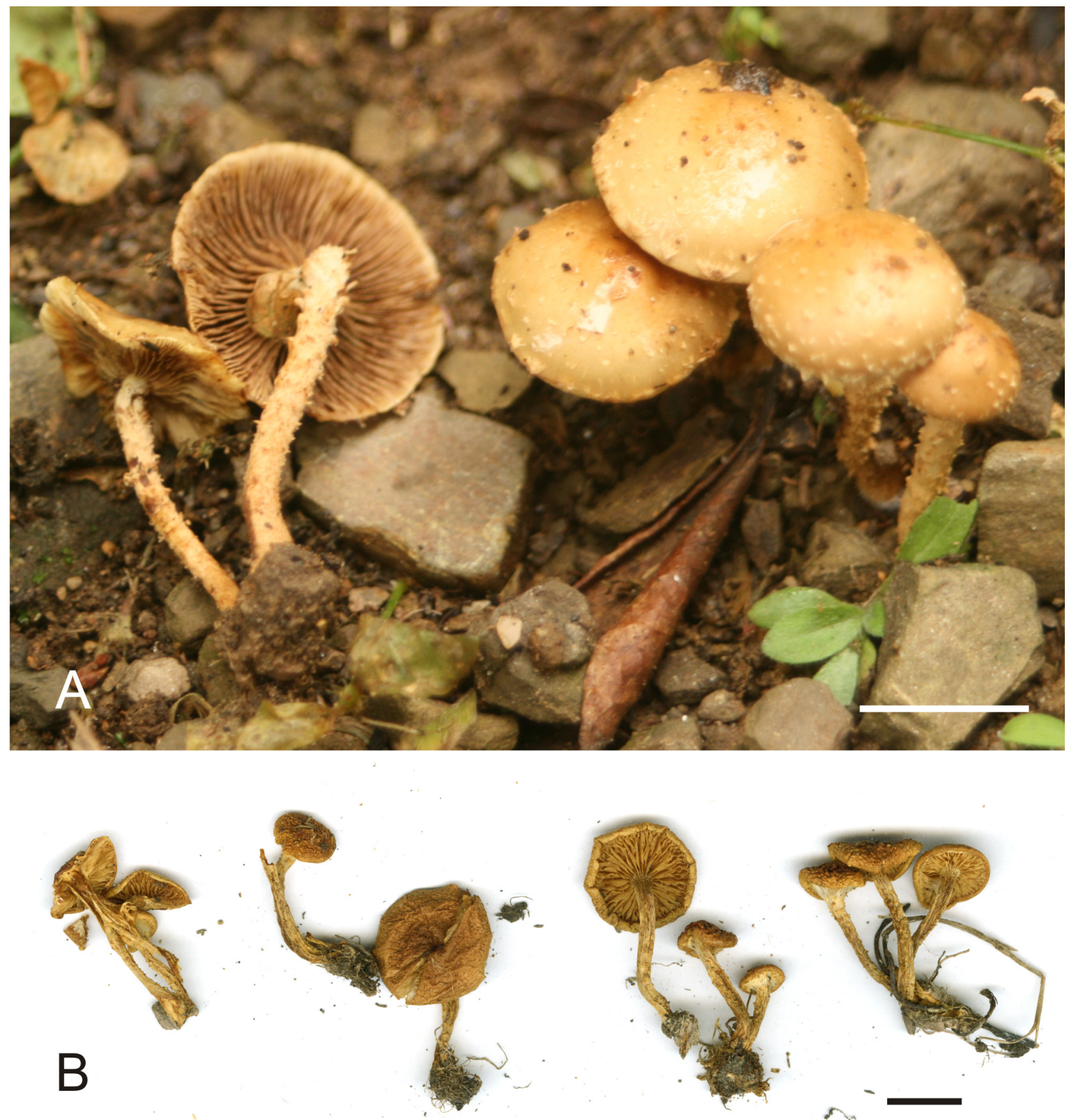

FIGURE 3: A-Pholiota oblita [Niveiro 976b (CTES)]. Material designated as type, B-Pholiota subflammans [Singer M 180 (LIL)]: Material designated as neotype. $\mathrm{Bar}=1 \mathrm{~cm}$ 


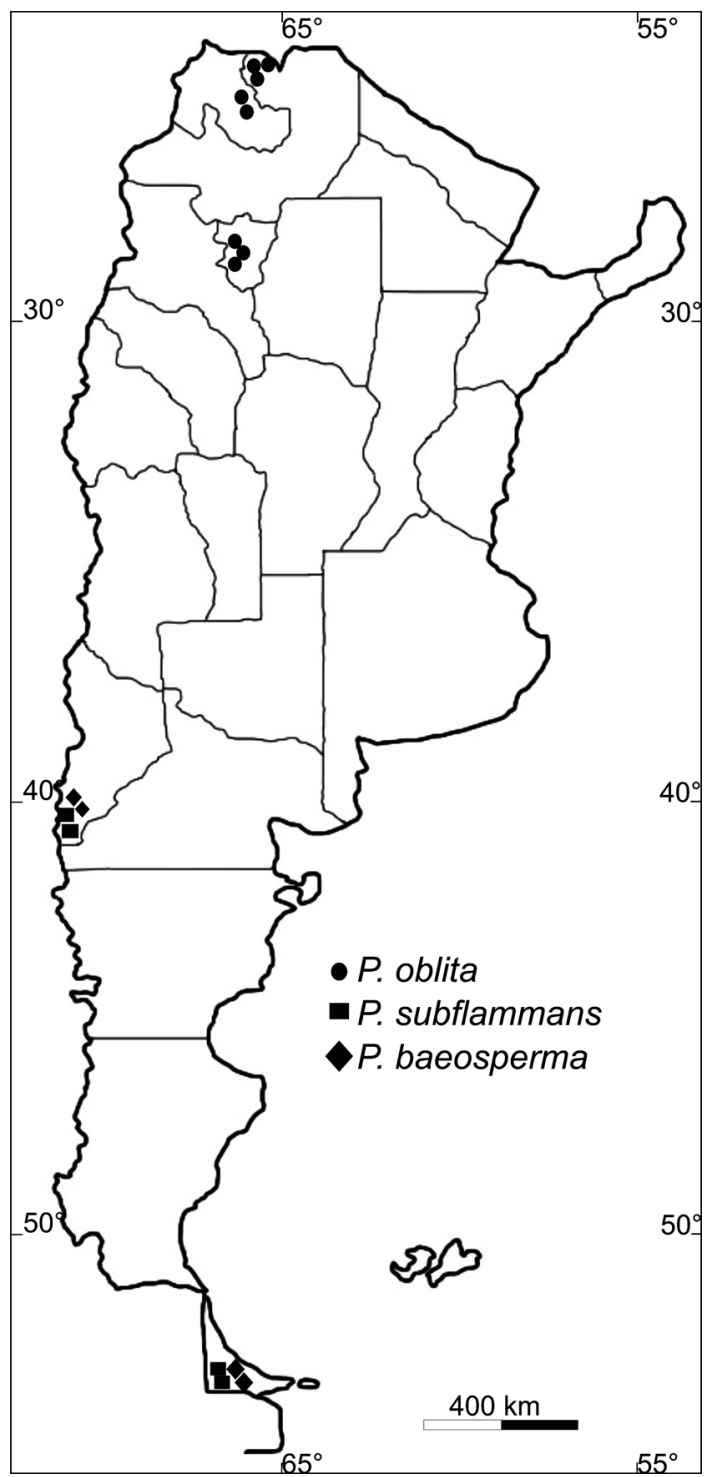

FIGURE 4: Distribution of $P$. oblita, $P$. subflammans, and $P$. baeosperma in Argentina. $P$. baeosperma is considered synonymous with P. subflammans. They have been shown separately only to exhibit that they share the same area of distribution.

A complete description of this species was realized by Singer (1952: 497) as P. subflammans, and Singer (1953: 217) and Singer \& Digilio (1952: 339) as P. baeosperma Singer.

Pholiota baeosperma Singer was included in section Lubricae (Fr.) Singer because it does not have scales on the pileus surface (Singer 1953: 217, Singer \& Digilio 1952: 339). However, according to Horak (1967: 358) the latter is synonymous with $P$. subflammans, having lost the scales by the action of rain or high atmospheric humidity. As a consequence, the pileipellis hyphae walls become gelatinous and the scales are lost, as was also observed in P. kauffmaniana A. H. Sm. and P. flammans in the Northern Hemisphere (Smith \& Hesler 1968).

\section{Key to species}

1- Basidiomata robust. Pileus (30) 40-80 (100) $\mathrm{mm}$ broad. Cheilocystidia up to $3 \mu \mathrm{m}$ broad. P. flammans

- $\quad$ Basidiomata more delicate. Pileus (7) $10-60 \mathrm{~mm}$ broad. Cheilocystidia 5-9 $\mu \mathrm{m}$ broad 2

2- Cheilocystidia elongated, 33-47 $\times 5.5-8.2 \mu \mathrm{m}$. Spores 6-7.5 $\times 3.8-5.5 \mu \mathrm{m}$. Lamellae narrow, up to $2.5 \mathrm{~mm}$ broad.. P. oblita

- $\quad$ Cheilocystidia shorter, $16-22 \times 3.5-7 \mu \mathrm{m}$. Spores 5.3-7 × 3-4.5 $\mu \mathrm{m}$. Lamellae wide, up to $5.5 \mathrm{~mm}$ broad. P. subflammans 


\section{Acknowledgments}

This work was supported by the research project PIP 112-200801-0602 from Consejo Nacional de Investigaciones Científicas y Técnicas (CONICET, Argentina). We are also grateful to the Argentinean National Parks Service for permission given to collect in protected areas and to the LIL and LPS herbaria for the loan of specimens and information given.

\section{References}

Horak, E. (1967) Fungi Austroamericani IV. Revisión de los hongos superiors de Tierra del Fuego o Patagonia en el Herbario de C. Spegazzini en La Plata. Darwiniana 14 (2-3): 355-376.

Largent, D.L. (1986) How to identify mushrooms to genus I: macroscopic features. Mad River Press, Eureka, pp. 1-165.

Largent, D.L. \& Baroni, T.J. (1988) How to identify mushrooms to genus VI: Modern genera. Mad River Press, Eureka, pp. 1277.

Lodge, J., Ammirati, J.F., O’Dell, T.E., Mueller, G.M., Huhndorf, S.M., Wang, C.J., Stokland, J.N., Schmit, J.P., Ryvarden, L., Leacock, P.R., Mata, M., Umaña, L., Wu, Q.F. \& Czederpiltz, D. (2004) Terrestrial and lignicolous macrofungi. In G.M. Mueller et al. (eds), Biodiversity of fungi. Inventory and monitoring methods. Elsevier Academic Press, San Diego, pp. $127-172$.

Maerz, A. \& Paul, M.R. (1930) Dictionary of color. McGraw-Hill Book Company, Inc. New York.

Mcneill, J.C., Barrie, F.R., Buck, W.R., Demoulin, V., Greuter, D.L., Hawksworth, D.L., Herendeen, P.S., Knapp, S, Marhold, K., Prado, J., Prud'Homme van Reine, G.F., Smith, G.F. \& Wiersema, J.H. (2012) International Code of Nomenclature for algae, fungi and plants (Melbourne code). Regnum Vegetabile 154. Koeltz Scientific Books.

Mueller, G.M. \& Wu, Q. (1997) Mycological contributions of Rolf Singer: field itinerary, index to new taxa, and list of publications. Fieldiana, Botany 38: 1-124. http://dx.doi.org/10.5962/bhl.title.2626

Niveiro, N. \& Albertó, E.O. (2012) Checklist of the Argentine Agaricales 2. Coprinaceae and Strophariaceae. Mycotaxon 120: 505. http://www.mycotaxon.com/resources/checklists/NiveiroAlberto-v120-checklist.pdf (complete paper, 38 p.).

Singer, R. (1952) Type studies on Agarics III. Lilloa 25: 465-514.

Singer, R. (1953) The agarics of the Argentine sector of Tierra del Fuego and limitrophous regions of the Magallanes area. Part 2. The brown-spored genera (except Cortinarius). Sydowia 7: 206-265.

Singer, R. (1986) The Agaricales in Modern Taxonomy. $4^{\text {th }}$ ed. Koeltz Scientific Books, Koenigstein, pp. 1-981.

Singer, R. \& Digilio A.P.L. (1952) [1951] Pródromo de la Flora Agaricina Argentina. Lilloa 25: 6-461.

Smith, A.H. \& Hesler, L.R. (1968) The North American Species of Pholiota. Hafner Publishing Company, New York, pp. 1349.

Spegazzini, C. (1887a) Fungi patagonici. Boletín de Academia Nacional de Ciencias de la Republica Argentina. 11: 5-64.

Spegazzini, C. (1887b) Fungi fuegiani. Boletín de Academia Nacional de Ciencias de la Republica Argentina. 11: 135-308.

Thiers, B. (2013 - continuously updated) Index Herbariorum: A global directory of public herbaria and associated staff. New York Botanical Garden's Virtual Herbarium. http://sweetgum.nybg.org/ih/ 